\title{
シンポジウム 慢性呼吸不全
}

（6）慢性呼吸不全のリハビリテーション

\author{
虎の門病院呼吸器科冲中記念成人病研究所 \\ 谷本普一蒲田 英明岡野弘田村昌士
}

\section{SYMPOSIUM ON CHRONIC RESPIRATORY FAILURE \\ (6) REHABILITATION OF CHRONIC RESPIRATORY FAILURE}

\section{Hiroichi Tanimoto, M.D., Hideaki Kamata, M.D., Hiroshi Oxano, M.D. and Masao TAmura, M.D.}

\begin{abstract}
Department of respiratory disease of Toranomon Hospital, Tokyo.
\end{abstract}
Okinaka Memorial Institute for Medical Research

\section{研究目的}

慢性呼吸不全は肺や気道の不可逆的な破壊がそ の形態学的背景となつているので, リハビリテー ションは,これらの疾患の治療上重要な意義をも つるのである.最近わが国でも、リハビリテーシ ョンへの関心がようやくもたれはじめるが，その 実施面ではまだ殆どなされていないのが現状であ る。われわれは昭和 42 年より現在まで約 8 年間, その多くが慢性呼吸不全を示す慢性肺疾患のリ八 ビリテーションを行なつてきたが，今回はそのリ ヘビリテーションの実際と, 治療効果の生理学的 機序，さらにアンケート調査による患者の追跡調 查について報告する。

リハビリテーションとは，患者が社会復帰する ためのすべての手段や過程が含まれるが，医学的 には，1）患者の教育，2）肺理学療法の実施， 3）運動寮法とくKポータプル酸素吸入装置を使 用する歩行練習，4）外来に打ける継続管理，5） 日常生活の指導などである。

\section{対象患者}

昭和 42 年から昭和 49 年むで, 当科でリハビリテ ーションを施行した患者は, 慢性肺気腫97名をは じとして総数 694名である（表 1 ）. 疾患の内訳
は，種々の慢性肺疾患が含まれるが，大部分は慢 性閉塞性肺疾患である，年令分布は慢性肺気腫お よび慢性気管支炎では，大部分が中年以降である が，他は各年令で同しょうな分布を示す．性別で は男女比は 1.6：1で, やや男性か゚多い。

平均りハビリテーション期間は，気管支喘息の 3.8週からびまん性沉細気管支炎の10.8週まで種 々であり, 疾患の重篤度に医汇例するが, 全体 の平均は 5.2 週である。

表 1.リハビリテーションを施行した肺疾患 (1967 1974)

\begin{tabular}{|c|c|c|c|c|c|c|c|c|}
\hline \multirow{2}{*}{ 浒惢名 } & \multirow{2}{*}{$\begin{array}{l}\text { 絡 } \\
\text { 数 }\end{array}$} & \multicolumn{2}{|c|}{ 性 別 } & \multicolumn{2}{|r|}{ 年 } & \multicolumn{2}{|l|}{ 令 } & \multirow{2}{*}{ 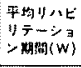 } \\
\hline & & 然 & 女 & $<20 t$ & $21-40 T$ & $41 \sim 60 \neq$ & $>61 \%$ & \\
\hline 拱性值気的 & 97 & 96 & 1 & & & 16 & 81 & 7.2 \\
\hline 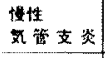 & 66 & 44 & 22 & & 5 & 28 & 33 & 5.2 \\
\hline 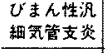 & 50 & 37 & 13 & & 9 & 31 & 10 & 10.8 \\
\hline 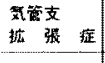 & 49 & 21 & 28 & 3 & 20 & 18 & 8 & 5.7 \\
\hline 気管支喘息 & 391 & 208 & 183 & 28 & 179 & 127 & 57 & 3.8 \\
\hline 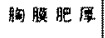 & 24 & 17 & 7 & & 5 & 15 & 4 & 7.0 \\
\hline 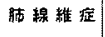 & 17 & 9 & $B$ & 1 & 1 & 6 & 9 & 5.8 \\
\hline ât & 694 & 432 & 262 & 32 & 219 & 241 & 202 & 5.2 \\
\hline
\end{tabular}




\section{リハビリテーションの方法}

\section{1）患者教育}

リハビリテーション開始前に，患者に，気管支 や肺の構造や呼吸のしくみ、リハビリテーション の意義や内容について，映画やパンフレットを用 い，分りやすく解説する。

\section{2) 肺理学療法}

肺理学療法をはじめる前に, 患者を椅子に坐ら せ，できる範囲で，屈伸を主とする体操を行な う。われわれは肺理学療法をグループ練習の形て 施行しているが，はじめての患者には，理学療法 土が個別的に指導している。

a) 腹式（横隔膜）呼吸

まずからだの各筇を驰緩させる，腹式呼吸は， 呼気時高位にたもたれていた横隔膜を，吸気時腹 を膨らませることにより下方へひき下げ，横隔膜 の上下の可動範囲を增し，肺の伸縮度をたかか， 換気の効率をよくする呼吸法である。呼吸練習の 方法は，Haasの方法を一部変えた筆者らの方法 で行ない，8項目からなる，練習 Iは仰卧位，II は仰臥位で膝を立てた体位，四は側臥位で行な う，右手を胸部に，左手を腹部に报き，右手は胸 部の動きを抑兄，左手は腹筋の動きを介助する。 IVは頭低位ベットで砂のうを用い，Vは坐位，立 位，歩行時之順々に練習を進める．VIは呼気の練 習で，ローソクの焰を吹く，吸気は鼻孔より 1.5 〜 2.0秒で吸入し，乎気はその $2 \sim 3$ 倍かけて， 口をすぼめてゆつくり口から呼出する。

b ) 体位ドレナーシ

体位ドレナージは，各気管支の解剖学的区分に 基づき，種々の体位をとることにより，重力を利 用し，少ないェネルギーで効率よく痰の揢出を促 す方法である。

練習は 8 項目からなる。練習 I は坐位で上体を 前後, 左右に傾ける練習. II は仰臥位之腹臥位の 体位転換，III側臥位で上体を前後に廻寸練習， IVは下腹部に枕入れ腹臥位をとる。Vは頭低位 ベットで仰卧位，Vは同じく頭低位べットで側卧 位をとる。VIは頭低位べットで仰卧位をとり，上
体を側上方へ挙上させる，䜣は頭と上体をべット から床上へ下降させ，上体が $45^{\circ}$ の傾斜となるよ うにする．その踪背中や胸部を手で軽く印くか， バイブレーターを用い，乲の喀出を助ける．また 同時にコントロールされた咳のしかたを覚えさせ る。

3）ポータブル酸素吸入装置使用による歩行練 習

ポータブル酸素吸入装㥀は，われわれが日本酸 素株式会社と共同で開発したもので，液体酸素を アルミニウムの容器に入れ，肩から下げ，携帯で きるようにしたものである．毎分 $4 l$ の酸素が気 化し， nasal cannulaで 1 時間継続使用できる．息 切れのために歩行できない慢性呼吸不全患者に， 歩行へのきつかけを与え，患者はこの装固を使用 し，可能な範囲の歩行を毎日行ない，その距離を 次第に延ばしていく.

\section{成䌅およひ考案}

1）腹式（横隔膜）呼吸の生理学的機序

63才から82才の慢性肺気腫10名について（表 2 )，腹式呼吸の前後で換気諸量を検討した，腹 式呼吸を6分間行なうと，図1のように酸素消費 量, 肺胞換気量は変らないが， 1 回換気量が增 之, 苸吸数, 分時換気量, 死腔換気率が減り, 酸素当量, 肺胞換気量に対する酸素消費量の比率 $\left(\dot{\mathrm{V}}_{2} / \mathrm{VA}\right)$ が減少する，これらの結果は，腹式 呼吸が効率のよい呼吸であることを示するのであ り，腹式呼吸の評価にはこれらの係数を指標とす ることができる。

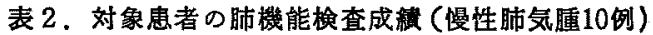

\begin{tabular}{|c|c|c|c|c|c|c|c|c|c|}
\hline 遮例 & 年公" & & $\%$ vC & FEVI.0\% & $\% \mathrm{TLC}$ & $\% \mathrm{RV}$ & RV/TLC & PMI\% & $\mathbf{R}$ \\
\hline 武 0 & 82 & 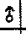 & 80 & 35 & 117 & 145 & 52 & 9.0 & 6.2 \\
\hline 0 & 75 & $\hat{\theta}$ & 81 & 30 & 124 & 172 & 58 & 5.3 & 6.2 \\
\hline 市。 & 66 & 3 & 94 & 38 & 120 & 161 & 51 & 4.6 & 2.8 \\
\hline$\$ 0$ & 72 & $s$ & 85 & 37 & 124 & 183 & 60 & 2.8 & \\
\hline 浜 0 & 65 & $\hat{s}$ & 100 & 37 & 120 & 150 & 49 & 2.3 & \\
\hline 0 & 70 & $\delta$ & 115 & 20 & 150 & 198 & 54 & 7.4 & 13.9 \\
\hline 侓 0 & 67 & $\hat{a}$ & 89 & 19 & 147 & 220 & 59 & 6.4 & 12.7 \\
\hline 接 0 & 65 & s & 114 & 21 & 134 & 173 & 48 & 2.9 & 8.4 \\
\hline 伸 0 & 73 & है & 75 & 34 & 107 & 154 & 60 & 3.7 & 6.3 \\
\hline 40 & 63 & $\hat{b}$ & 64 & 27 & 124 & 220 & 66 & 13.5 & 8.5 \\
\hline
\end{tabular}



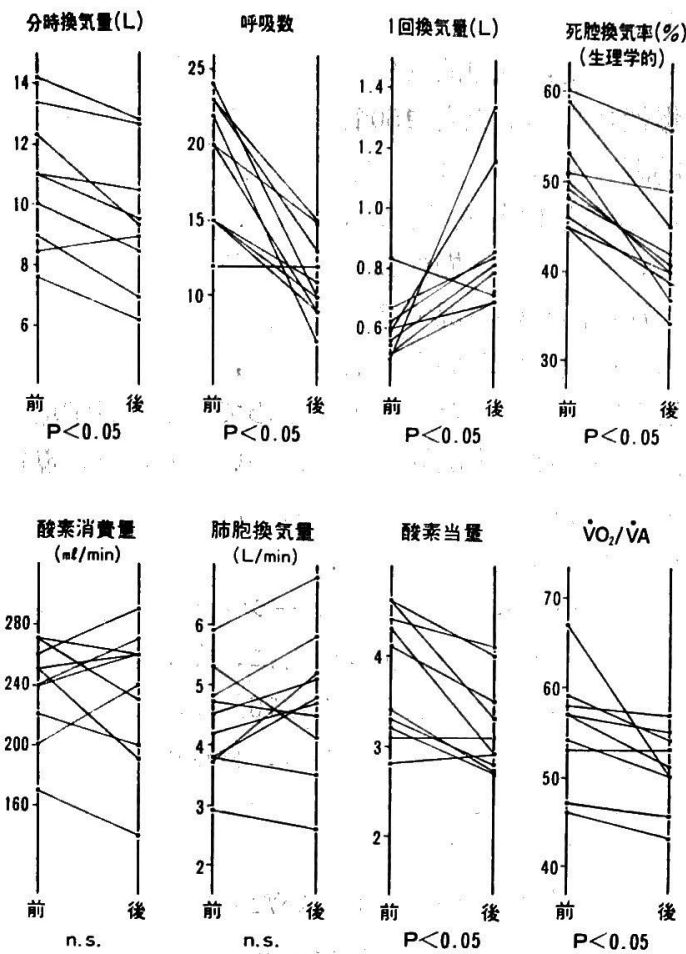

$\dot{\mathrm{V}} \mathrm{O}_{2} / \dot{\mathrm{VA}}$

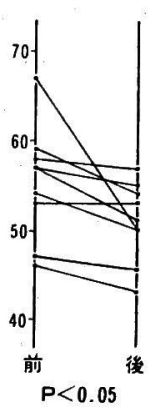

図 1. 腹式呼吸前後の換気諸量（慢性肺気腫10名）

2）ポータブル酸素吸入装置による歩行練習 67才の慢性肺気腫患者に，この装置を用い， 練習を行なつた。歩行距離は図 2 のように, 最初

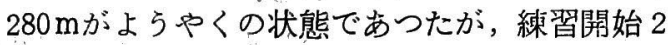
カ月半後の 9 月中旬以降は, 酸素を時々吸入しな くても歩けるょうになり，10月下旬には，酸素を 吸入せず $750 \mathrm{~m}$ の歩行が可能となつた。なおこの 患者はこの期間中, 肺理学療法を行なつている が, 安静時肺機能や血液ガスの変化はなく,これ らの改善は, 可逆的な肺機能の改善によるるので はなく, 換気効率の改善を含め, 下肢筋の歩行能 力の向上を示するのと考学らる.

このよらにして歩行練習を行なつた患者全例 に, 歩行能力の増加を認めた。慢性呼吸不全患者 5 名の平均歩行距離は, 練習開始前 $576 \mathrm{~m}$, 練習 後1590mである.

3）リハビリテーションの肺生理学的評価

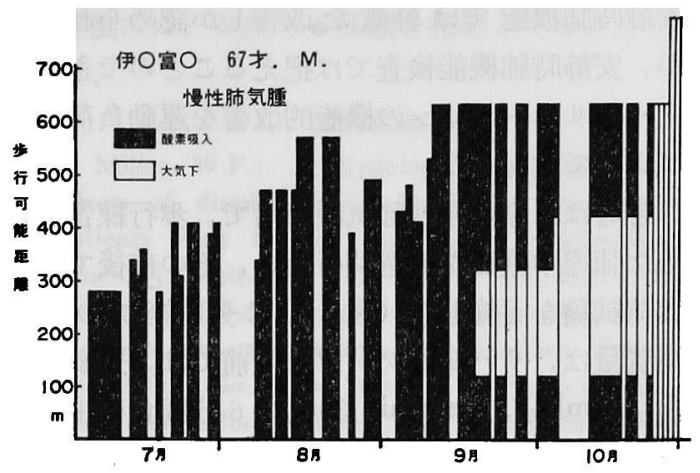

図 2,Portable酸素吸入装置使用に上る歩行練習

腹式呼吸，体位ドレナージ，歩行練習を含め たリハビリテーションの評価および治療効果判定 は，な掵議の多い問題である，われわれは可逆 的な因子の関与することの少ない慢性肺気腫50名 について, 平均 7.2週間施行したリハビリテーシ ョンの前後で, 肺機能検查および血液ガス検查を 行ない,それらを比較検討した。

肺活量は $2.5 \%$ の有意差で, 軽度の増加を認め たが， 1 秒率, 全肺気量, 残気量の変化はみられ なかつた. 動脈血ガス分折では、リハビリテーシ

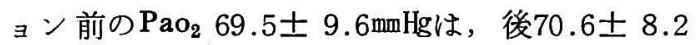
$\mathrm{mm} \mathrm{Hg}$ となり, 有意差は認められないが, $\mathrm{PaCO}_{2}$ は 前44.3土 $5.2 \mathrm{~mm} H g$ が，後 $42.7 \pm 5.0 \mathrm{~mm} \mathrm{Hg}$ となり, $5 \%$ \%危険率で有意差を示した.

以上のよらに,リハビリテーションの効果は,

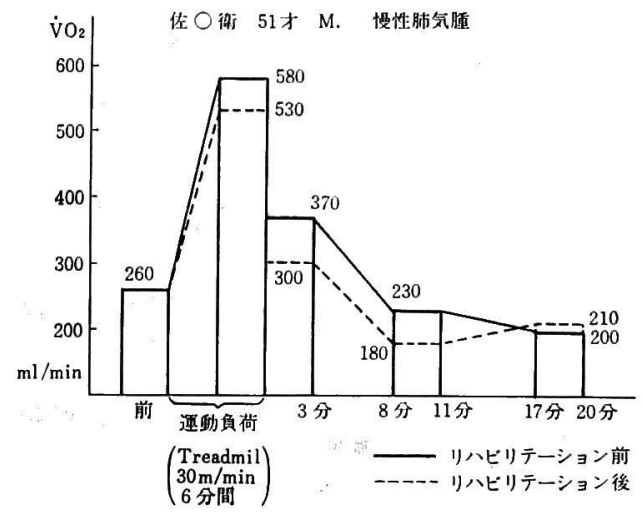

図3、リハビリテーション前後の運動時酸埰負債 
安静時肺機能 では 軽微な 改善しか認められない が，安静時肺機能検査では把えることのできない リハビリテーションの機能的改善を運動負荷試験 によつて検討した。

患者は51才の慢性肺気腫患者で，歩行練習を含 めた肺理学療法を 6 週間行ない, その前後で運動 負荷試験を実施した（図 3 ). 1 分間当りの酸素 消費量は，リハビリテーション前では，運動負荷 前 $260 \mathrm{ml} /$ 分, treadmil $30 \mathrm{~m} /$ 分 6 分間負荷中 580 $\mathrm{ml} /$ 分, 運動直後から 3 分まで $370 \mathrm{ml} /$ 分, 運動後 8 分から11分まで $230 \mathrm{ml} /$ 分, 17 分から20分まで $200 \mathrm{ml} /$ 分で, リハビリテーション後では，運動 負荷前 $260 \mathrm{ml} /$ 分, treadmil $30 \mathrm{~m} /$ 分 6 分間負荷中 $530 \mathrm{ml} /$ 分, 運動直後から 3 分まで $300 \mathrm{ml} /$ 分, 運 動後 8 分から11分まで $180 \mathrm{ml} /$ 分, 17分から 20 分 まで $210 \mathrm{ml} /$ 分であつた。すなわちハビリテーショ ンにより，一定の運動負荷に対する酸素負債の減 少が認められ，機能的改善が示唆された。

4）アンケート調査によるハビリテーションの 評価

慢性呼吸不全のリハビリテーションの評価は， 肺生理学的な評価と同時に，その患者が実際に社 会に復帰でき，社会的貢献がなされたかどうかな ぞの総合的評価が重要である．そのためには長期 間にわたる厳密な比較試験が必要であるが，社会 復帰あるいは日常生活 の 状況についてのアンヶ 一ト調査も, 総合評価のひとつの方法と考えられ
る.

この度, 可逆的变化を示す気管支喘息を除き， 慢性呼吸不全患者 150名にアンケートを送り, 追 跡調査を行なつた。このうち住所変更などによ る返送分18名を除く 132名の回収率は72\%94名 で，らち38名は慢性肺気腫である。

社会活動の現況では，現在働いている人63名67 \%，働いていない人31名33\%で，このうち11名約 $1 / 3$ が呼吸不全のため仕事をやめている。日常環境 内での肺理学療法施行状況についてみると, 現在 も腹式呼吸をつづけている人は $71 \%$ ，体位ドレナ ージは30\%となつている.

患者からみたリハビリテーションの効果（図 4) は, 息切れの改善は $81 \%$, 作業能力の向上 は47\%に，生活意欲の向上は76\%に認められ，自 覚的改善は著しいものがある．職場へ復帰できた

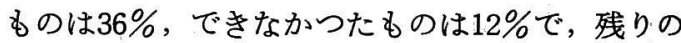
不変52\%は，もともと働いていいなかつたり，は じめから働いていたりしていた人である.

家族からみたハビリテーションの効果は，から だの調子もよく，仕事の能力も向上し，精神的に 明るくなつたとするもの $41 \%$ ，息苦しさはわから ないよらだが，仕事の能力が向上し元気になつた とするもの $23 \%$ ，約 $2 / 3$ が家族の目からも改善が 認められることを示している。

アンケートの回答者はハビリテーションについ て，積極的な考え方をるつ人が多いと考えられる

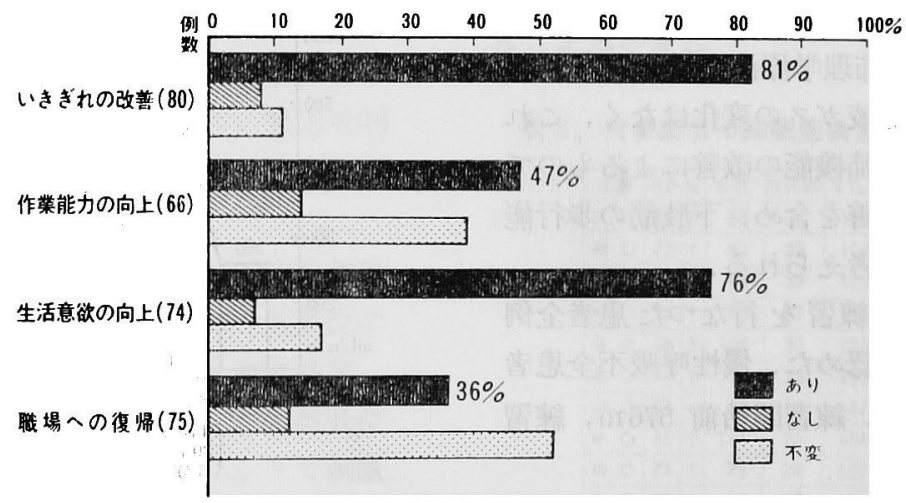

図 4.患者からみだリハビリテーションの効果 
し、また記名調査であるため, 調査側に有利な回 答を寄せる傾向も否定できないが，患者や家族 のリハビリテーションに対する主観的評価の意義 は，過小評価することはできないと考えられる。

\section{結 論}

1）慢性呼吸不全の治療上,リハビリテーショ ンの意義は重要である。 8 年間慢性呼吸不全患者 694名にリハビリテーションを実施し，そのうち 94名に追跡調査を行なつたが，その81\%に息切れ の改善を, $76 \%$ に生活意欲の改善を，36\%に職場 復㷌を認めた。

2）リハビリテーションの肺生理学的評価は, 通常の肺機能検査および動脈血ガス分析では困難 であるが，運動負荷試験による酸素負債測定が適 当である、リバビリテーションの機能的改善の機 序は, 一定の運動負荷に対する酸素負債の減少が 主であると考えられる。

3）慢性肺気尰に抢ける腹式（横隔膜）呼吸の 生理学的機序は, 酸素当量の減少，肺胞換気量に 対する酸素消費量の比率の減少であり, 腹式呼吸
の評価には，これらの係数を指標とすることがで きる。

\section{参考文献}

1) Miller, W.F.: A physiologic evaluation of the effects of diaphragmatic breathing training in patients with chronic pulmonary emphysema. Amer. J. Med., 17: 471, 1954. -2) Haas, A.: Essentials of living wtih pulmonary emphysema, A guide for patients and their families, Patient Publication No. 4 the Institute of Physical Medicine and Rehabilitation. New York Medical Center, 1963. -3) Pierce, A.K.: Responses to exercise training in patients with emphysema. Arch. inter. Med., 113: 28, 1964. 4) Barach, A.L.: A treatment manual for patients with pulmonary emphysema. Grune \& Stratton, New York and London, 1969. -5) Petty, T.L.: Intensive and rehabilitative respiratory care. Lea \& Febiger, Philadelphia, 1971. -6) 谷本普一; 同野 弘, 城所泰子, 望月博之, 田村昌士, 本間日, 臣：慢性閉塞性肺䛈患に対するリメビリテーショ ソ，内科， $23: 465 ， 1969$ ，一7) 本間日臣：慢性肺 不全患者の治寮と管理，第18回日本医学会総会会 誌，1116，1971，一8) 谷本普一，淮田英明：肺理 学瘦法, 綜合臨床, $22: 430,1973 .-9)$ 谷本普 一, 中田紘一郎, 溥田英明, 汹野弘, 田村昌士: 携带用酸案吸入装置による慢性肺不全の運動港法。 内科, $32: 898,1973$. 